\title{
Molecular mechanisms of Mn induced neurotoxicity: RONS generation, genotoxicity, and DNA-damage response
}

\author{
Julia Bornhorst ${ }^{1,2}$, Sören Meyer ${ }^{1,2}$, Till Weber ${ }^{2}$, Carolina Böker², Talke Marschall², \\ Aswin Mangerich ${ }^{3}$, Sascha Beneke ${ }^{4}$, Alexander Bürkle ${ }^{3}$ and Tanja Schwerdtle ${ }^{2}$ \\ ${ }^{1}$ Graduate School of Chemistry, University of Münster, Münster, Germany \\ ${ }^{2}$ Institute of Food Chemistry, University of Münster, Münster, Germany \\ ${ }^{3}$ Department of Biology, Molecular Toxicology Group, University of Konstanz, Konstanz, Germany \\ ${ }^{4}$ Institute of Veterinary Pharmacology and Toxicology, University of Zürich, Zürich, Switzerland
}

Scope: In industrial countries dietary manganese (Mn) intake is well above the estimated average requirement. Moreover, exposure to high Mn levels is known to cause adverse neurological effects in humans, which are yet mechanistically not well understood.

Methods and results: This study aimed to identify early modes of action of Mn induced toxicity in mammalian brain cells. In primary porcine brain capillary endothelial cells induction of reactive oxygen and nitrogen species was identified as the most sensitive endpoint $\left(\geq 0.5 \mu \mathrm{M} \mathrm{MnCl}\right.$ ). In cultured human astrocytes $\mathrm{MnCl}_{2}$ was rapidly bioavailable, induced a slight increase of cellular reactive oxygen and nitrogen species levels and a slight decrease of ATP levels (1-100 $\mu \mathrm{M} \mathrm{MnCl}_{2}$ ), while no genotoxic effects were observed. However, $\mathrm{MnCl}_{2}$ $(\geq 1 \mu \mathrm{M})$ efficiently disturbed DNA-damage-induced poly(ADP-ribosyl)ation in human astrocytes, which indicates sensitization of cells to genotoxic treatment. Additionally, we determined Mn levels in infant formula, which are generally massively supplemented with Mn and thus might pose an important source for Mn overexposure.

Conclusion: The observed inhibition of DNA-damage-induced poly(ADP-ribosyl)ation in human astrocytes by exposure-relevant $\mathrm{Mn}$ concentrations indicate that in terms of $\mathrm{Mn}$ the existing guidelines for infant formula but also drinking water should be critically reconsidered.

\section{Keywords:}

Infant formula / Manganese / Neurotoxicity / Oxidative stress / Poly(ADP-ribosyl)ation

\section{Introduction}

Manganese (Mn) is a widely distributed essential trace element. It is necessary for brain development and the reg-

Correspondence: Professor Tanja Schwerdtle, Institute of Food Chemistry, Westfälische Wilhelms-Universität Münster, Corrensstraße 45, 48149 Münster, Germany

E-mail: Tanja.Schwerdtle@uni-muenster.de

Fax: +49-251-83-33396

Abbreviations: ICP-OES, inductively coupled plasma emission spectrometry; Mn, manganese; NA, nicotinic acid; PAR, poly(ADP-ribose); PARG, poly(ADP-ribose) glycohydrolase; PARP-1, poly(ADP-ribose) polymerase-1; PBCECs, porcine brain capillary endothelial cells; RONS, reactive oxygen and nitrogen species; TBS, Tris-buffered saline; TCA, trichloroacetic acid ulation of numerous biochemical and cellular reactions, for example as constituent of important metalloenzymes, such as arginase, pyruvate carboxylase, or superoxide dismutase [1,2]. Mn occurs naturally in water, air, soil, and food and exists as both inorganic and organic species, with the inorganic $\mathrm{Mn}^{2+}$ and $\mathrm{Mn}^{3+}$ species being more prevalent. For the general population dietary intake is the major source for Mn [3]. Highest Mn concentrations are seen in herbal food, including grain, rice, nuts, and tea.

The ubiquitous presence of $\mathrm{Mn}$ in food accounts for the fact that in industrial countries dietary Mn intake (2$5 \mathrm{mg}$ (day) is well above the estimated average requirement. As a consequence Mn deficiency is practically nonexistent in the general population [4]. Nevertheless, in case of high occupational (welding, mining), medical (total parenteral nutrition, contrast agents), and environmental (dietary 
supplements, pesticides) Mn exposure, excessive levels of Mn can accumulate in the brain, especially in the substantia nigra $[5,6]$. This has been shown to result in a specific clinical central nervous system disorder (referred to as manganism), which shares multiple clinical analogies with Parkinson's disease [6-11]. To date neither Mn uptake in the brain nor the molecular mechanisms behind Mn induced neurotoxic effects are fully understood [12]. On the cellular level Mn is believed to exert toxicity via a number of mechanisms, including impairment in iron homeostasis, excitotoxicity, disruptive effects on the neurochemistry of neurotransmitters ( $\gamma$-aminobutyric acid, dopamine, glutamate), protein aggregation, mitochondrial dysfunction as well as direct and indirect formation of reactive oxygen and nitrogen species (RONS) [5, 13, 14].

Excessive production of RONS can lead to reactions with macromolecules, such as DNA, lipids, and proteins. It has been proposed that DNA damage contributes to neurological dysfunction, including Parkinson's disease, underscoring the critical importance of DNA repair for neural homeostasis $[15,16]$. Defective responses to DNA damage and an impairment of genomic stability are to date increasingly linked with diseases such as Alzheimer's and Parkinson's disease [17-19]. In this regard, the role of the DNA damage response protein poly(ADP-ribose) polymerase-1 (PARP-1) in CNS disorders was investigated in the last years [20,21]. In response to DNA strand breaks two members of the PARP superfamily, PARP-1 and PARP-2, are rapidly activated and transfer ADP-ribosyl units from $\mathrm{NAD}^{+}$onto themselves and other target proteins, thus producing protein-coupled ADPribose polymers of up to 200 units. PARP-1 is responsible for about $90 \%$ of cellular poly(ADP-ribose) (PAR) formation $[22,23]$. Poly(ADP-ribose) glycohydrolase (PARG) and ADP-ribosylhydrolase-3 (ARH3) contribute to PAR degradation [21]. PARP-1 is a $116-\mathrm{kDa}$ protein that is involved in several biological pathways and poly(ADP-ribosyl)ation affects proteins involved in transcription, replication, telomere maintenance, genomic stability, chromatin organization, and DNA repair [24-26]. Overactivation of PARP-1 results in cellular $\mathrm{NAD}^{+}$depletion, energy failure, and ultimately cell death [27-29]. PARP-1 inhibition [28-30] might decrease genomic stability due to a disturbance of DNA repair pathways. To date little is known about the effects of Mn on the cellular DNA damage response. Recently, we identified Mn-induced inhibition of $\mathrm{H}_{2} \mathrm{O}_{2}$-stimulated poly(ADP-ribosyl)ation in human cervix carcinoma cells as a highly sensitive endpoint for Mn cellular toxicity, although the underlying mechanism awaits further evaluation [31].

This study aimed to investigate whether $\mathrm{Mn}$ is capable to inhibit damage-induced poly(ADP-ribosyl)ation in brain cells. In parallel, further potentially sensitive modes of action, including oxidative stress and genotoxicity were studied, thereby also taking into account the cellular bioavailability of $\mathrm{Mn}$.

\section{Material and methods}

\subsection{Preparation of $\mathrm{MnCl}_{2}$ stock solution}

$\mathrm{MnCl}_{2}$ (>99.995\% purity, Sigma-Aldrich, Deisenhofen, Germany) stock solutions in sterile distilled water were prepared shortly before each experiment to prevent oxidation.

\subsection{Cell culture and incubation with the test compounds}

Astrocytic cultures (CCF-STTG1 (CCL-185 ${ }^{\mathrm{TM}}$ )) obtained from the American Type Culture Collection (Bethesda, MD, USA) and freshly isolated porcine brain capillary endothelial cells (PBCECs) were used as in vitro model systems. CCF-STTG1 cells were cultured in RPMI 1640 (Biochrom, Berlin, Germany), supplemented with 10\% FCS (PAA Laboratories, Pasching, Austria), $1.4 \mathrm{mM}$ L-glutamine (Biochrom), $100 \mathrm{U} / \mathrm{mL}$ penicillin, and $100 \mathrm{mg} / \mathrm{mL}$ streptomycin (PAA) (RPMI culture medium), under human cell culture standard conditions at $37^{\circ} \mathrm{C}$ with $5 \% \mathrm{CO}_{2}$ in air and $100 \%$ humidity. Logarithmically growing cells were treated with $\mathrm{MnCl}_{2}$ as described for the respective experiments. PBCECs were isolated, cultivated, and cryoconserved according to [32]. For the respective experiments on day 2 in vitro (DIV2) PBCECs were gently thawed and seeded $\left(250000 / \mathrm{cm}^{2}\right)$ on rat tail collagen-coated 96-well culture plates or on gelatincovered glass coverslips in plating medium (Medium 199 Earle supplemented with $10 \%$ newborn calf serum, $0.7 \mathrm{mM}$ L-glutamine, $100 \mu \mathrm{g} / \mathrm{mL}$ gentamycin, $100 \mathrm{U} / \mathrm{mL}$ penicillin, $100 \mu \mathrm{g} / \mathrm{mL}$ streptomycin (all Biochrom)) at $37^{\circ} \mathrm{C}$ with $5 \% \mathrm{CO}_{2}$ and $100 \%$ humidity. After reaching confluence (DIV4), the plating medium was replaced by serum-free culture medium (DMEM/Ham's F 12 (1:1) containing $4.1 \mathrm{mM}$ L-glutamine, $100 \mu \mathrm{g} / \mathrm{mL}$ gentamycin, $100 \mathrm{U} / \mathrm{mL}$ penicillin, $100 \mu \mathrm{g} / \mathrm{mL}$ streptomycin (all Biochrom)), and $550 \mathrm{nM}$ hydrocortisone (Sigma-Aldrich) to induce differentiation. Incubation with $\mathrm{MnCl}_{2}$ was performed on DIV7.

\subsection{Cellular bioavailability}

Mn levels in CCF-STTG1 cells were measured after 2-48-h incubation with $\mathrm{MnCl}_{2}$ by inductively coupled plasma emission spectrometry (ICP-OES, iCAP 6300, Thermo Fisher Scientific), as reported previously [31,33]. Briefly, the $\mathrm{MnCl}_{2}$ exposed cells were trypsinized, collected by centrifugation, washed with ice-cold PBS, and the cell number as well as cell volume were measured by an automatic cell counter (Casy ${ }^{\circledR}$ TTC, Roche Innovatis AG) in each sample. After digesting the cells with $65 \% \mathrm{HNO}_{3} / 30 \% \mathrm{H}_{2} \mathrm{O}_{2}(1: 1)$ at $95^{\circ} \mathrm{C}$ for at least $12 \mathrm{~h}$ samples were diluted with water and $\mathrm{Mn}$ was quantified by ICP-OES. 
For Mn efflux studies CCF-STTG1 cells $\left(2 \times 10^{6}\right)$ were exposed to $\mathrm{MnCl}_{2}$ for $24 \mathrm{~h}$ and subsequently washed with RPMI culture medium. After $0.5-24$-h postincubation with fresh, non-Mn incubated RPMI culture medium and after quantification of the respective cell numbers and volumes, total Mn amounts were determined by ICP-OES.

\subsection{Cellular RONS level}

The ability of Mn to increase the cellular RONS level was determined by a carboxy-DCFH-DA based reader test system, applying three different incubation protocols. Thus, 24-h preincubation with $\mathrm{MnCl}_{2}$ before dye loading were carried out, as well as incubation with $\mathrm{MnCl}_{2}$ immediately after dye loading or a combination of both. In all sets of experiments the RONS generation was monitored up to $24 \mathrm{~h}$ after dye loading and was normalized to control cells (dye-loaded cells without $\mathrm{MnCl}_{2}$ treatment) to consider naturally occurring and procedure induced RONS. Briefly, $48 \mathrm{~h}$ after seeding (42000 cells/well of a 96-well plate) CCF-STTG1 cells were preincubated for $24 \mathrm{~h}$ with $\mathrm{MnCl}_{2}$. In PBCECs 24-h preincubation with $\mathrm{MnCl}_{2}$ was carried out on DIV6. After preincubation and before dye loading CCF-STTG1 cells were washed twice with phenolred free medium (Biochrom), PBCECs were washed with serum-free culture medium. CCF-STTG1 cells were exposed to $15 \mu \mathrm{M}$ carboxy-DCFH-DA (5(\&6)-Carboxy-2',7'-dichlorodihydrofluorescein-diacetate (Invitrogen, OR, USA)) for $15 \mathrm{~min}$ and PBCECs were incubated with $10 \mu \mathrm{M}$ carboxy-DCFH-DA for $10 \mathrm{~min}$ at $37^{\circ} \mathrm{C}$. Subsequently cells were washed and finally incubated with $\mathrm{H}_{2} \mathrm{O}_{2}$ (positive control) or $\mathrm{MnCl}_{2}$. Intracellular oxidation of carboxy-DCFH, which correlates with the intracellular RONS level, was determined (ex. $485 \mathrm{~nm} / \mathrm{em} .535 \mathrm{~nm}$ ) by a microplate reader (Infinite Pro M200, Tecan, Salzburg, Austria) immediately after incubation; kinetics were constructed up to $24 \mathrm{~h}$ after incubation. Data were always applied to a control (dye-loaded cells without a RONS generator), to exclude an interfering fluorescence of the matrix.

\subsection{Determination of DNA strand breaks}

DNA strand breaks were determined by the alkaline unwinding technique [31]. Logarithmically growing CCF-STTG1 cells (200 000) were exposed to $\mathrm{MnCl}_{2}$ for 2, 24 or $48 \mathrm{~h}$. In case of combination experiments with $\mathrm{H}_{2} \mathrm{O}_{2}$, after preincubation with $\mathrm{MnCl}_{2}$, cells were coincubated with $100 \mu \mathrm{M} \mathrm{H}_{2} \mathrm{O}_{2}$ for $5 \mathrm{~min}$. Thereafter the culture medium was removed, cells were washed with cold PBS and lesions were quantified and calculated as described earlier [31].

\subsection{Formation of micronuclei}

To investigate the induction of micronuclei, logarithmically growing CCF-STTG1 cells were seeded in 6-well plates on
Alcian blue (Sigma-Aldrich) coated glass coverslips. After $48 \mathrm{~h}$ cells were incubated with $\mathrm{MnCl}_{2} .5 \mathrm{~h}$ after $\mathrm{MnCl}_{2}$ incubation cytochalasin B (Sigma-Aldrich) was coincubated (final concentration $1 \mu \mathrm{g} / \mathrm{mL}$ ). Forty-three hours after cytochalasin B exposure, cells were fixed with an ice-cold fixation solution (90\% methanol $/ 10 \% \mathrm{PBS},-20^{\circ} \mathrm{C}$ ) for $10 \mathrm{~min}$, dried in the air, stained with acridine orange $(125 \mathrm{mg} / \mathrm{L}$ in PBS) (Roth, Karlsruhe, Germany) for $10 \mathrm{~s}$ and finally analyzed by fluorescence microscopy (Zeiss, Oberkochen, Germany). Per coverslip at least 1000 binucleated cells were counted; analysis was carried out after coding of slides.

\subsection{Measurement of energy related nucleotides}

The impact of a 2-h incubation of $\mathrm{MnCl}_{2}$ on the levels of the cellular energy related nucleotides (ATP, ADP, ADP-ribose, $\mathrm{AMP}, \mathrm{NAD}^{+}, \mathrm{NADH}$ ) were quantified by a reliable ion-pair RP HPLC based method [33]. Briefly, $10 \times 10^{6} \mathrm{MnCl}_{2}$ exposed cells were trypsinized, resuspended in cold PBS containing $5 \%$ FCS, and cell number was determined by an automatic cell counter (Casy ${ }^{\circledR}$ TTC). The nucleotides were extracted by adding $300 \mu \mathrm{L} 0.5 \mathrm{M} \mathrm{KOH}$ and pulling the pellet 10 times through a 23-gauge needle. Subsequently, the extracts were neutralized with $60-\mu \mathrm{L}$ phosphoric acid (10\%). After centrifugation the nucleotides were separated and quantified immediately by ion-pair RP HPLC/DAD.

\subsection{Cellular levels of poly(ADP-ribosyl)ation}

Cellular poly(ADP-ribosyl)ation was measured as described earlier [34] with minor modifications as indicated later. CCFSTTG1 cells were seeded on Alcian blue coated glass coverslips, cultured for $48 \mathrm{~h}$ and incubated with $\mathrm{MnCl}_{2}$ for $2-48 \mathrm{~h}$. PBCECs were cultured on gelatin-covered (Sigma-Aldrich) glass coverslips and incubated with $\mathrm{MnCl}_{2}$ on DIV6 for 2-48 h. Poly(ADP-ribosyl)ation was stimulated by 10-min incubation with $250 \mu \mathrm{M} \mathrm{H}_{2} \mathrm{O}_{2}$. Subsequently, cells were rinsed with PBS (containing $1 \mathrm{mM} \mathrm{MgCl}$ ) and fixed with ice cold methanol $\left(-20^{\circ} \mathrm{C}, 8 \mathrm{~min}\right)$. After fixation cells were rinsed twice with Tris-buffered saline (TBS) and blocked in TBS/0.3\% Tween $20 / 1 \%$ BSA (Roth) (TTB) at $30^{\circ} \mathrm{C}$ for $30 \mathrm{~min}$. Incubation with the primary anti-PAR antibody $10 \mathrm{H}$ [35] was carried out in blocking solution $(1: 300)$ at $30^{\circ} \mathrm{C}$ for $45 \mathrm{~min}$, followed by repeated washing steps with TBS containing $0.3 \%$ Tween 20 . The secondary, Alexa 488-conjugated anti-mouse antibody (Invitrogen) (dilution 1:250 in TTB) was applied accordingly. Coverslips were washed again and embedded in Vectashield mounting medium containing $1 \mu \mathrm{g} / \mathrm{mL}$ DAPI (Vector Laboratories Inc., Burlingame, CA, USA). Fluorescence analyses were performed applying a Zeiss Axio ImagerM2 wide field fluorescence microscope (Zeiss). At least 300 cell nuclei per slide were selected by DAPI staining. In the selected areas the relative Alexa-488 fluorescence intensities were quantified using Axio Vision (Version 4.5) imaging software (Zeiss). 
In case of nicotinic acid (NA) (VWR, Darmstadt, Germany) incubation studies, CCF-STTG1 cells were cultured on coverslips for $36 \mathrm{~h}$, preincubated with 15 or $30 \mu \mathrm{M}$ NA for $12 \mathrm{~h}$ and coincubated with $\mathrm{MnCl}_{2}$ for $2 \mathrm{~h}$. Subsequently, cellular PAR stimulation and quantification was carried out as described earlier.

\subsection{Relative PARP-1 gene expression}

Real time RT-PCR was performed for quantification of PARP1 and PARG mRNA levels. Briefly, $24 \mathrm{~h}$ after seeding of $2 \times$ $10^{6}$ astrocytes, cells were incubated with $\mathrm{MnCl}_{2}$ for $2-48 \mathrm{~h}$. All further steps were performed exactly as described earlier [36]. The respective forward (for) and reverse (rev) primers PARP-1 for 5'-CTTGGCCTGCACACTGTCTG-3', PARP-1 rev 5'-GCAGCGACTCTCAGATCCTG-3 (efficiency 101.3\%); PARG for 5'-CCTACTGGGTTGGTGACATT-3', PARG rev 5'-CGTAAGTGACATGCAATCGT-3' (efficiency 92.1\%); GA PDH for 5'-CTGCACCACCAACTGCTTAG-3', GAPDH rev 5'-GGCATGGACTGTGGTCATGAG-3'(efficiency 104.2\%) were applied. The thermal cycling program consisted of the following steps: $1.5 \mathrm{~min}$ at $95^{\circ} \mathrm{C}$ to activate polymerase, $40 \mathrm{cy}$ cles of $30 \mathrm{~s}$ at $95^{\circ} \mathrm{C}, 1 \mathrm{~min}$ at $60^{\circ} \mathrm{C}$, and $15 \mathrm{~s}$ at $72^{\circ} \mathrm{C}$. GAPDH expression was not significantly changed by $\mathrm{MnCl}_{2}$ in the observed concentration range and thus can be used in this approach as an adequate reference gene.

\subsection{Total PARP-1 protein level}

Total cellular PARP-1 protein level was quantified by SDSPAGE/Western blot analysis as described previously [31] with slight modifications. After 2-48-h incubation with $\mathrm{MnCl}_{2}$, CCF-STTG1 cells were trypsinized, resuspended with PBS containing $5 \%$ FCS, and cell numbers were measured by an automatic cell counter in each sample. After centrifugation, cells were resuspended on ice in proteinase inhibitor solution ( $1 \mathrm{mmol} / \mathrm{L}$ EDTA, $10 \mathrm{mmol} / \mathrm{L}$ sodium bisulfite, $0.01 \mathrm{mmol} / \mathrm{L}$ pepstatin, $0.1 \mathrm{mmol} / \mathrm{L}$ PMSF in PBS (Sigma-Aldrich)) and proteins were denatured by adding $100 \mu \mathrm{L}$ of $95^{\circ} \mathrm{C}$ hot SDSPAGE loading buffer $\left(10 \mathrm{~min}\right.$ at $\left.95^{\circ} \mathrm{C}\right)$. Afterwards respective protein aliquots (each referring to 70000 cells) were analyzed by $12 \%$ denaturating SDS-PAGE and transferred to a polyvinylidene difluoride (PVDF) membrane (GE Healthcare, Munic, Germany). After blocking with 5\% dry milk solution in PBS containing 0.1\% Tween20 (PBS-T) at room temperature, membranes were incubated with a primary antibody against PARP-1 (Enzo Life Sciences GmbH, Lörrach, Germany) in blocking solution $(1: 1000)$ overnight at $4^{\circ} \mathrm{C}$, followed by incubation with HRP-conjugated secondary antibody (Santa Cruz Biotechnology, Santa Cruz, USA) for $1 \mathrm{~h}$ at room temperature; actin (antibody 1:1500) served as loading control. Immunoreactive bands were detected by chemiluminescence using ECL prime detection reagents (GE Health- care) and a chemiluminescence imaging system (ChemiDocTM XRS, Bio-Rad, Munic, Germany). Protein levels were quantified by densitometric analysis with Quantity One software (Bio-Rad) and normalized to controls.

\subsection{Activity of recombinant PARP-1}

Activity of recombinant PARP-1 (expressed in a baculovirus system [37]) was quantified by a further established immunoslot-blot technique based on a test system published recently [38]. Briefly, after 2-min preincubation of PARP-1 (0.69 ng/ $\mu \mathrm{L}(61 \mathrm{nM})$ ) with $\mathrm{MnCl}_{2}$ in preincubation buffer (0.08 M HEPES pH 7.9, 10-nM $\mathrm{MgCl}_{2}, 0.2 \mathrm{mM}$ EDTA pH 7) at room temperature, the PARP-1 reaction was carried out for $5 \mathrm{~min}$ at $37^{\circ} \mathrm{C}$ in reaction buffer $\left(200 \mu \mathrm{M} \mathrm{NAD}{ }^{+}\right.$, 8.9$\mathrm{mg} / \mathrm{mL}$ GGAATTCC (Eurofins MWG Operon, Ebersberg, Germany), 0.08 M HEPES pH 7.9, $10 \mathrm{nM} \mathrm{MgCl}_{2}, 0.2 \mathrm{mM}$ EDTA pH 7). Poly(ADP-ribosyl)ation was stopped by adding an equal volume of $20 \%$ trichloroacetic acid (TCA), followed by a further dilution with $10 \%$ TCA in order to transfer $5 \%$ of each reaction to the membrane. Respective aliquots of $100 \mu \mathrm{L}$ were transferred to a PVDF membrane by a slot blotter (Minifold I system, $24 \mathrm{~mm}^{2} /$ slot; VWR), followed by a washing step with $10 \%$ TCA. The membrane was blocked overnight at $4^{\circ} \mathrm{C}$ in TNT $(10 \mathrm{mM}$ Tris $\mathrm{pH} 8,150 \mathrm{mM} \mathrm{NaCl}$, Tween $200.05 \%) / 5 \%$ dry milk and PAR polymers were detected by immunoblot analysis using a monoclonal PARantibody (10H) (1 h 1:1000, in blocking solution at RT) and a HRP-conjugated secondary antibody (1 h 1:1000 in blocking solution at RT). The immunoreactive bands were quantified as described earlier.

\subsection{Mn content in infant formula}

Mn concentrations in infant formula were quantified by ICPOES (ICP-OES Optima $7000^{\mathrm{TM}}$ DV, Perkin Elmer, Waltham, USA) after microwave digestion [39] (Anton Paar, Ostfildern, Germany). Approximately, $0.6 \mathrm{~g}$ of the substance was weighed out into a perfluoroalkoxy alkane (PFA) microwave vessel and gallium (internal standard (10 mg/L)) (Sigma-Aldrich), $0.5 \mathrm{~mL}$ hydrochloric acid and $3 \mathrm{~mL}$ nitric acid were added. The applied microwave program was a ramp up from 100 to $600 \mathrm{~W}$ within $5 \mathrm{~min}$, constant power for $5 \mathrm{~min}$, followed by further increase to $1000 \mathrm{~W}$, which was constant for the next $10 \mathrm{~min}$. Afterwards digested samples were diluted with distilled water in a $25 \mathrm{~mL}$ glass flask and the obtained solutions were analyzed by ICP-OES (Table 1). LOD for Mn was $0.072 \mu \mathrm{g} / \mathrm{L}$ calculated according to the $3 \sigma$-criterion [40]. Determinations of blank and certified reference material (CRM 414 (plankton) (Community Bureau of Reference of the Commission of the European Communities)) were performed periodically after 15 samples each. 
Table 1. Inductively coupled plasma emission spectrometry parameters (ICP-OES Optima $7000^{\mathrm{TM}}$ DV, Perkin Elmer) used for the measurements of the infant formulas

Parameters

\begin{tabular}{ll}
\hline Power & $1300 \mathrm{~W}$ \\
Nebulizer gas flow & $0.6 \mathrm{~L} / \mathrm{min}$ \\
Flow rate & $0.9 \mathrm{~mL} / \mathrm{min}$ \\
Nebulizer & Concentric glas nebulizer (Meinhard) \\
Spray chamber type & Cyclone \\
Position & Axial (position: $x=0 \mathrm{~mm}, y=15 \mathrm{~mm}$ ) \\
Wavelength & Manganese: $257.610 \mathrm{~mm}$ \\
& Gallium: $417.206 \mathrm{~mm}$ \\
\hline
\end{tabular}

\subsection{Statistical analysis}

All experiments were at least carried out three times at three different days, with at least three independent measurements. Using the raw data the mean SD was calculated and a statistical analysis was performed by using the unpaired Student's t-test. As indicated in the respective figure legends significance levels are $* p<0.05$, $* * p<0.01$, and ${ }^{* * *} p<0.001$.

\section{Results}

\subsection{Cytotoxicity and cellular bioavailability in cultured astrocytes}

The cytotoxicity of $\mathrm{MnCl}_{2}$ in CCF-STTG1 cells after 24- and 48-h incubation has been studied by our group and published before [33]. Briefly, regarding the endpoints cell num- ber and cell volume incipient cytotoxic effects were observed at $1000 \mu \mathrm{M}$ after 24-h incubation (cell number: $85 \pm 2 \%$ ) and at $500 \mu \mathrm{M}$ after 48 -h incubation (cell number: $76 \pm$ $7 \%)$, respectively. To avoid strong cytotoxic effects, the highest concentration applied in this study was $500 \mu \mathrm{M} \mathrm{MnCl}_{2}$. Mn bioavailability was assessed by measuring cellular Mn by ICP-OES. Comparing extracellular and cellular Mn concentrations after 2-h incubation with 1 and $10 \mu \mathrm{M} \mathrm{MnCl}_{2}$, an accumulation was observed in cells. At 50-500 $\mathrm{MM}$, however, the respective cellular $\mathrm{Mn}$ concentrations were lower as compared to the extracellular concentrations administered (Fig. 1A). Similar effects occurred after $24 \mathrm{~h}$ (partly shown in Fig. $1 \mathrm{~B}$ and $\mathrm{C}$ ) and 48-h incubation with $\mathrm{MnCl}_{2}$ [33].

The experiments regarding time dependency of $\mathrm{Mn}$ cellular bioavailability showed that in case of incubation with 50 or $500 \mu \mathrm{M} \mathrm{MnCl}_{2}$, cellular $\mathrm{Mn}$ reached a maximum after $0.5 \mathrm{~h}$ (Fig. 1B) and $1 \mathrm{~h}$ (Fig. 1C) of incubation, respectively. In the subsequent 23.5 or $23 \mathrm{~h}$ of incubation with $\mathrm{MnCl}_{2}$, cellular Mn levels were stable.

In a set of efflux experiments after 24-h incubation, the culture medium was replaced with fresh culture medium, not supplemented with $\mathrm{MnCl}_{2}$. Cells loaded with $50 \mu \mathrm{M} \mathrm{MnCl}_{2}$ were able to release the absorbed Mn nearly completely within $0.5 \mathrm{~h}$ after medium replacement (Fig. 1B), whereas after incubation with $500-\mu \mathrm{M} \mathrm{MnCl} \mathrm{Mn}_{2}$ the efflux was not complete within $12 \mathrm{~h}$ (Fig. 1C).

\subsection{Impact on the cellular RONS level}

In CCF-STTG1 cells $\mathrm{MnCl}_{2}$ showed only a moderate increase of the cellular RONS level in case of all three incubation

A

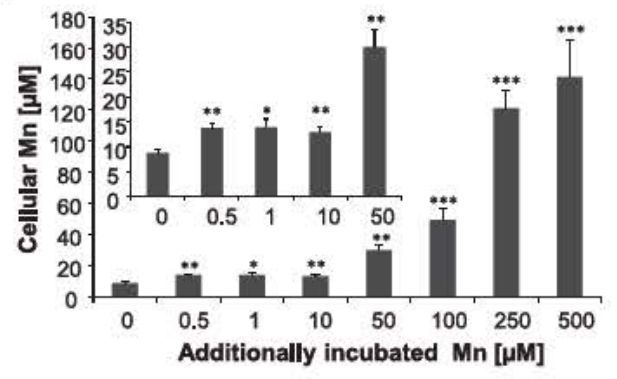

B

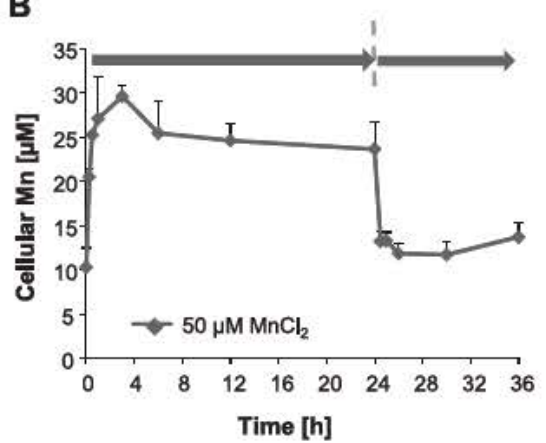

C

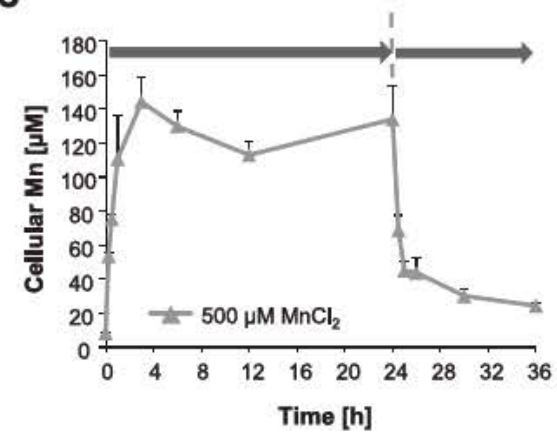

Figure 1. Cellular bioavailability of $\mathrm{MnCl}_{2}$ in CCF-STTG1 cells. Cellular Mn levels after 2-h incubation with $\mathrm{MnCl}_{2}$; an additional cutout is displayed for the concentration range 0-50 $\mu \mathrm{M} \mathrm{MnCl} 2$ (A). Time dependent cellular bioavailability of $\mathrm{Mn}$ after 0.25-24-h incubation with $50 \mu \mathrm{M}$ (B) or $500-\mu \mathrm{M}$ (C) $\mathrm{MnCl}_{2}$ and efflux profile of the $\mathrm{Mn}$ loaded cells after media replacement by fresh, not $\mathrm{Mn}$ incubated culture media (marked by the dashed line). Shown are mean values of at least four independent determinations + SD. 
A

$=1 \mu \mathrm{M} \mathrm{MnCl}_{2}=10 \mu \mathrm{M} \mathrm{MnCl}_{2}=50 \mu \mathrm{M} \mathrm{MnCl}_{2}$ $=100 \mu \mathrm{M} \mathrm{MnCl}=500 \mu \mathrm{M} \mathrm{MnCl}$

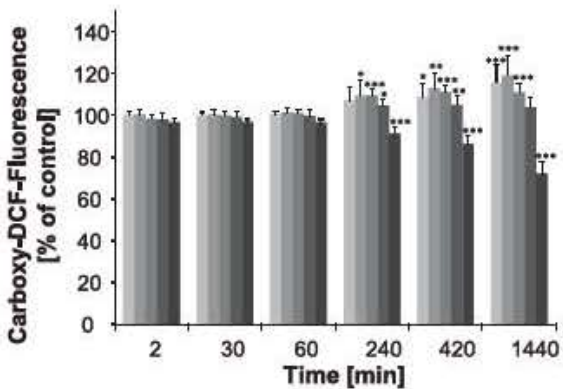

B

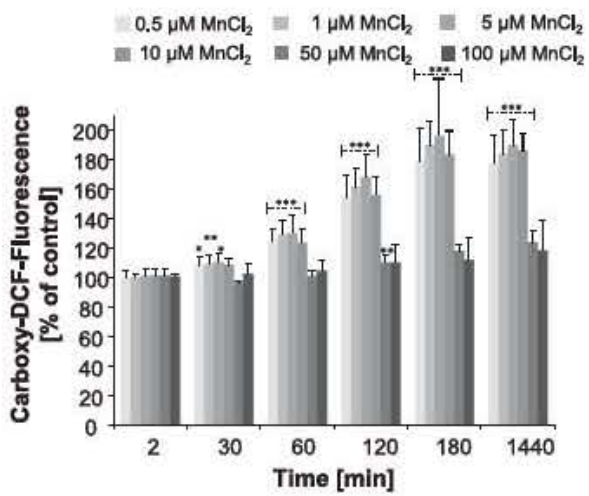

Figure 2. Effect of $\mathrm{MnCl}_{2}$ on the cellular reactive oxygen and nitrogen species level of CCF-STTG1 cells (A) and porcine brain capillary endothelial cells (B). Cellular reactive oxygen and nitrogen species level as measured by carboxy-DCF fluorescence after 24-h preincubation with $\mathrm{MnCl}_{2}$, dye loading and subsequent $\mathrm{MnCl}_{2}$ postincubation. Shown are mean values $(+\mathrm{SD})$ of at least eight measurements, which were applied to dye-loaded control cells. protocols. Comparing the incubation protocols, highest, but still very slight, effects (10-15\% increase) were achieved after combined 24-h pre- and postincubation with $\mathrm{MnCl}_{2}$ (Fig. 2A, data not shown for pre- or postincubation only). The decrease in the RONS-related fluorescence level at $500 \mu \mathrm{M} \mathrm{MnCl}_{2}$ was due to the cytotoxicity of $\mathrm{MnCl}_{2}$, which caused a disturbance of the cell monolayer. The operational reliability and sensitivity of the test system was always ensured by treating cells with $200 \mu \mathrm{M} \mathrm{H}_{2} \mathrm{O}_{2}$ as positive substance, excluding among others that the stress of the cells during the test procedure might have affected the results. A total of $200 \mu \mathrm{M} \mathrm{H}_{2} \mathrm{O}_{2}$ timedependently increased the cellular RONS levels, reaching a maximum of $250 \%$ after $1 \mathrm{~h}$ of incubation (data not shown). In order to elucidate the RONS generation in primary brain cells, PBCECs were used in the next set of experiments; brain capillary endothelial cells are known to be highly sensitive toward Mn induced toxic effects $[14,41]$. In PBCECs the RONS increasing potential of $\mathrm{MnCl}_{2}$ was much stronger and faster than in astrocytes. Strongest effects were induced after a 24-h pre- and postincubation with $0.5-10 \mu \mathrm{M} \mathrm{MnCl}_{2}$ (Fig. 2B, data not shown for pre- or postincubation only). At higher, still noncytotoxic, $\mathrm{MnCl}_{2}$ concentrations $(50,100 \mu \mathrm{M})$ PBCECs seem to be able to cope with $\mathrm{Mn}$ induced oxidative stress.

\subsection{Determination of DNA strand breaks and micronuclei formation}

Genotoxic effects on DNA and chromosomal level were studied by the alkaline unwinding technique [31] and the cytokinesis-block micronucleus assay [42], respectively. After 2-, 24-, and 48-h incubation $\mathrm{MnCl}_{2}$ did not significantly induce DNA stand breaks in CCF-STTG1 cells (Fig. 3A). After $48 \mathrm{~h}$ of incubation $\mathrm{MnCl}_{2}$ did also not increase the number of micronuclei in the cultured astrocytes; the respective cytokinesis-block proliferation indexes of $\sim 1.8$ indicated no impact of $\mathrm{Mn}$ on cell proliferation up to $250 \mu \mathrm{M}$ $\mathrm{MnCl}_{2}$ (Fig. 3B).

\subsection{Effects on poly(ADP-ribosyl)ation}

After short-term (2 h) and long-term $(24,48$ h) incubation $\mathrm{MnCl}_{2}$ exerted no effect on poly(ADP-ribosyl)ation in both nonstimulated CCF-STTG1 cells and PBCECs (data not shown). Since in unstressed cells the presence of PAR is in generally quite low, in the next set of experiments cellular poly(ADP-ribosyl)ation was stimulated by $\mathrm{H}_{2} \mathrm{O}_{2}$, to study the
A

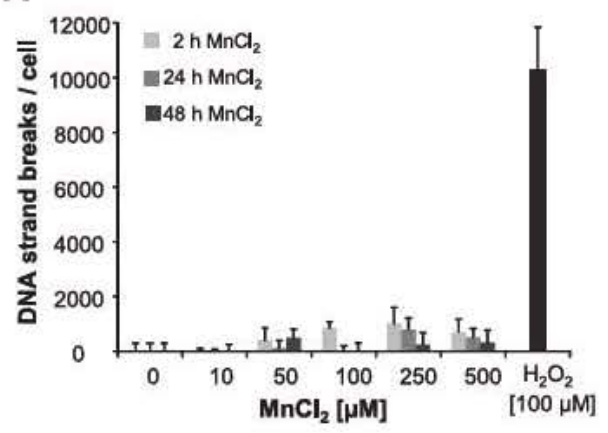

B

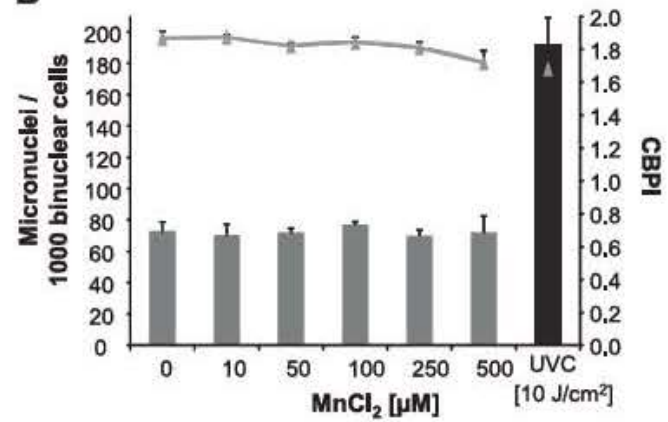

Figure 3. Generation of DNA strand breaks (A) and micronuclei induction (B) in CCF-STTG1 cells after incubation with $\mathrm{MnCl}_{2}$. (A) DNA strand breaks after 2-, 24-, and 48-h incubation with $\mathrm{MnCl}_{2}$ as quantified by the alkaline unwinding technique. Five-minute incubation with $100-\mu \mathrm{M} \mathrm{H}_{2} \mathrm{O}_{2}$ served as positive control. (B) Five-hour $\mathrm{MnCl}_{2}$ preincubation and $43-\mathrm{h}$ incubation of cytochalasin $\mathrm{B}$ in the continued presence of $\mathrm{MnCl}_{2}$. A total of $10 \mathrm{~J} / \mathrm{cm}^{2} \mathrm{UVC}$ irradiation served as positive control. Shown are each mean values of at least three independent determinations with three measurements each + SD. 
A

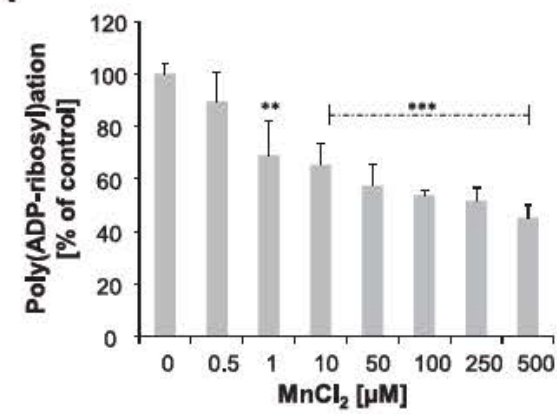

C

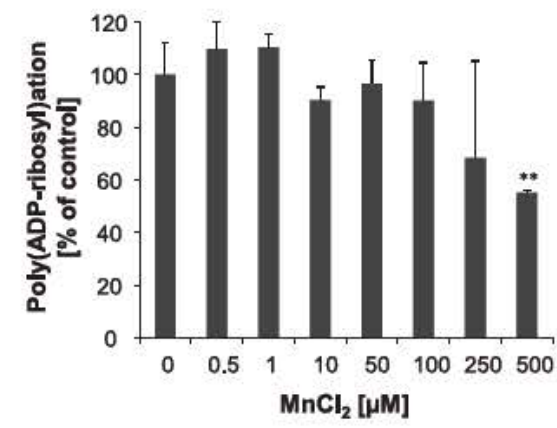

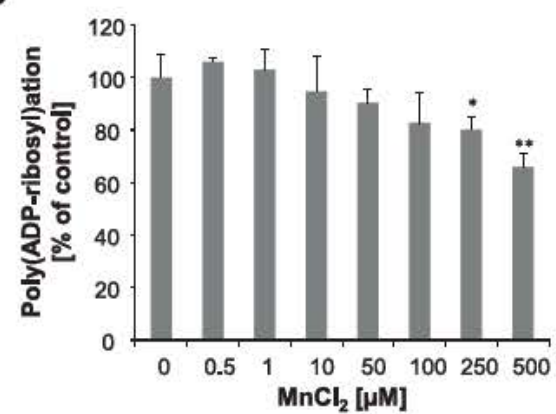

D

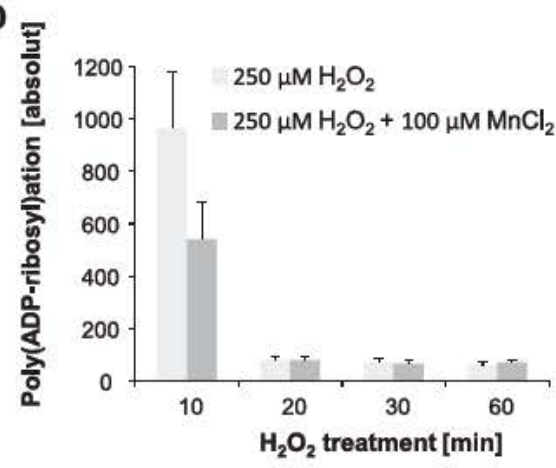

Figure 4. Induction of poly(ADP-ribosyl)ation by $\mathrm{H}_{2} \mathrm{O}_{2}$ and inhibitory effect of $\mathrm{MnCl}_{2}$. Logarithmically growing CCF-STTG1 cells were preincubated with $\mathrm{MnCl}_{2}$ for $2(\mathrm{~A}), 24(\mathrm{~B})$, or $48 \mathrm{~h}(\mathrm{C})$ and treated with $250 \mu \mathrm{M} \mathrm{H}_{2} \mathrm{O}_{2}$ for $10 \mathrm{~min}$ in the continued presence of Mn. (D) Time course of poly(ADP-ribosyl)ation after treatment with $\mathrm{H}_{2} \mathrm{O}_{2}$ in the presence and absence of Mn. Logarithmically growing CCF-STTG1 cells were preincubated with $\mathrm{MnCl}_{2}$ for $2 \mathrm{~h}$ and treated with $100 \mu \mathrm{M} \mathrm{H} \mathrm{O}_{2}$ for $10,20,30$, or $60 \mathrm{~min}$ in the continued presence of $\mathrm{Mn}$. (E) Porcine brain capillary endothelial cells were preincubated with $\mathrm{MnCl}_{2}$ for $2 \mathrm{~h}$ and poly(ADP-ribosyl)ation was stimulated with $250 \mu \mathrm{M} \mathrm{H} \mathrm{H}_{2} \mathrm{O}_{2}$ for $10 \mathrm{~min}$. (A-E) Poly(ADP ribosyl)ation was determined by immunological staining of poly(ADP-ribose) and quantified via fluorescence microscopy; mean values of at least three determinations with at least 200 cells each + SD . impact of Mn on this DNA damage related signaling reaction. In cultured human astrocytes a preincubation with subcytotoxic concentrations of $\mathrm{MnCl}_{2}$ significantly decreased the extent of $\mathrm{H}_{2} \mathrm{O}_{2}$-induced poly(ADP-ribosyl)ation. In doing so, inhibition largely depended on incubation time with $\mathrm{MnCl}_{2}$. Thus, after 2-h $\mathrm{MnCl}_{2}$ incubation already $1 \mu \mathrm{M} \mathrm{MnCl}_{2}$ significantly inhibited $\mathrm{H}_{2} \mathrm{O}_{2}$-stimulated poly(ADP-ribosyl)ation (Fig. 4A). After long-term incubation $(24,48 \mathrm{~h})$ inhibition occurred only at higher concentrations (Fig. $4 \mathrm{~B}$ and C).

In $\mathrm{H}_{2} \mathrm{O}_{2}$-stimulated primary $\mathrm{PBCECs}, \mathrm{MnCl}_{2}$ significantly inhibited poly(ADP-ribosyl)ation after 2-h incubation (Fig. 4E). In contrast after 24- or 48-h incubation no significant inhibition was observed (data not shown).

Since the impact of $\mathrm{Mn}$ on $\mathrm{H}_{2} \mathrm{O}_{2}$-induced poly(ADP. ribosyl)ation was stronger in cultured astrocytes than in PBCECs all further experiments related to this signaling reaction were carried out in CCF-STTG1 cells. Time course experiments, investigating the level of poly(ADP-ribosyl)ation after 10-, 20-, 30-, and 60-min $\mathrm{H}_{2} \mathrm{O}_{2}$ incubation in the absence and presence of $\mathrm{MnCl}_{2}$, revealed that the observed decrease in $\mathrm{H}_{2} \mathrm{O}_{2}$-stimulated poly(ADP-ribosyl)ation is not due to a delay of the signaling reaction (Fig. 4D).

Supplementation of cultured astrocytes with the $\mathrm{NAD}^{+}$ precursor NA indicated that the observed Mn-induced inhibition of $\mathrm{H}_{2} \mathrm{O}_{2}$-stimulated poly(ADP-ribosyl)ation results not from a diminished $\mathrm{NAD}^{+}$concentration (data not shown).

\subsection{PARP-1 and PARG gene expression}

In CCF-STTG1 cells, after all incubation times, $\mathrm{MnCl}_{2}$ did not decrease PARP-1 gene expression, but even significantly increased PARP-1 mRNA levels after 2-h incubation (Table 2). Similar to PARP-1, PARG gene expression was increased after short-term incubation (Table 2). 
Table 2. Effect of $\mathrm{MnCl}_{2}$ on PARP-1 and PARG gene expression. CCF-STTG1 cells were incubated with $\mathrm{MnCl}_{2}$ for $2-48 \mathrm{~h}$. Relative gene expression was determined by real time RT-PCR; mean values of at least three independent determinations with three measurements each referring to the control and normalized to GAPDH \pm SD

\begin{tabular}{|c|c|c|c|c|c|c|}
\hline \multirow[b]{2}{*}{$\mathrm{MnCl}_{2}[\mu \mathrm{M}]$} & \multicolumn{3}{|c|}{$P A R P-1$ gene expression normalized to GAPDH } & \multicolumn{3}{|c|}{$P A R G$ gene expression normalized to GAPDH } \\
\hline & $2 \mathrm{~h}$ & $24 \mathrm{~h}$ & $48 \mathrm{~h}$ & $2 \mathrm{~h}$ & $24 \mathrm{~h}$ & $48 \mathrm{~h}$ \\
\hline 0 & $1.00 \pm 0.07$ & $1.00 \pm 0.11$ & $1.00 \pm 0.09$ & $1.00 \pm 0.07$ & $1.00 \pm 0.03$ & $1.00 \pm 0.11$ \\
\hline 1 & $0.95 \pm 0.07$ & $1.10 \pm 0.13$ & $0.88 \pm 0.03^{*}$ & $1.19 \pm 0.12^{*}$ & $1.22 \pm 0.04^{* * *}$ & $1.16 \pm 0.05^{*}$ \\
\hline 10 & $1.46 \pm 0.14^{* * *}$ & $1.15 \pm 0.18$ & $1.03 \pm 0.11$ & $1.74 \pm 0.08^{* * *}$ & $1.29 \pm 0.07^{* * *}$ & $1.16 \pm 0.06$ \\
\hline 50 & $1.57 \pm 0.15^{* * *}$ & $0.98 \pm 0.16$ & $1.22 \pm 0.12^{* * *}$ & $1.84 \pm 0.20^{* * *}$ & $1.14 \pm 0.12$ & $1.69 \pm 0.06^{* * *}$ \\
\hline 100 & $1.70 \pm 0.20^{* * *}$ & $1.18 \pm 0.13$ & $1.10 \pm 0.03$ & $1.54 \pm 0.28^{* * *}$ & $0.87 \pm 0.12$ & $1.00 \pm 0.10$ \\
\hline
\end{tabular}

\subsection{Cellular PARP-1 protein level}

Western blot experiments demonstrated no impact of $\mathrm{MnCl}_{2}$ on total PARP-1 protein level in the cultured astrocytes after 2- (Fig. 5A), 24-, and 48-h (data not shown) incubation with up to $500 \mu \mathrm{M} \mathrm{MnCl}$.

\subsection{Effects on poly(ADP-ribosyl)ation of recombinant PARP-1}

To determine whether Mn alters the activity of recombinant PARP-1 a nonradioactive immuno-slot-blot assay was further established (details given in Experimental Procedures) based on an existing test system [38]. The applicability of the established assay was verified by the PARP inhibitor 3-aminobenzamide (Fig. 5B). Two-minute preincubation of recombinant PARP-1 with $\mathrm{MnCl}_{2}$ did not diminish the PARP-1 activity in the range of $0.5-4000 \mu \mathrm{M}$ (Fig. 5C). In order to come closer to the cellular system and because of the controversial discussions in literature about the existing $\mathrm{Mn}$ species in biological media $[43,44]$, in a next step CCF-STTG1 cells were incubated with $\mathrm{MnCl}_{2}$ for $2 \mathrm{~h}$. Then an aliquot of the supernatant was preincubated with purified recombinant PARP-1. However, also under these conditions, Mn did not affect the activity of recombinant PARP-1 (data not shown).

\subsection{Effect on the level of energy related nucleotides}

A 2-h incubation with $\mathrm{MnCl}_{2}$ did not significantly affect the cellular levels of the nicotinamide adenine nucleotides, $\mathrm{NAD}^{+}$and $\mathrm{NADH}$ (Fig. 6A). ATP (1-100 $\left.\mu \mathrm{M} \mathrm{MnCl}_{2}\right)$ and ADP-ribose $\left(\geq 250 \mu \mathrm{M} \mathrm{MnCl}_{2}\right)$ levels were significantly

\section{A}

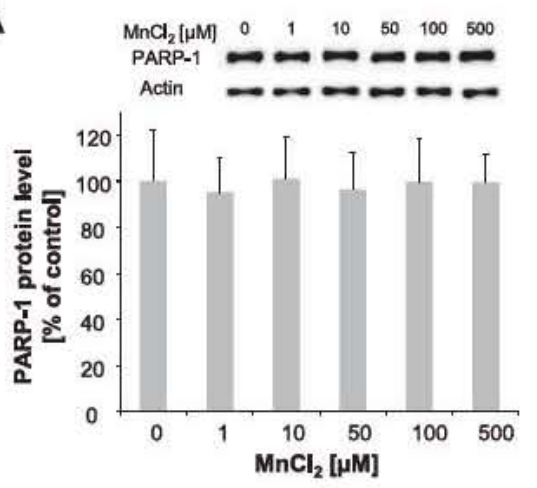

B

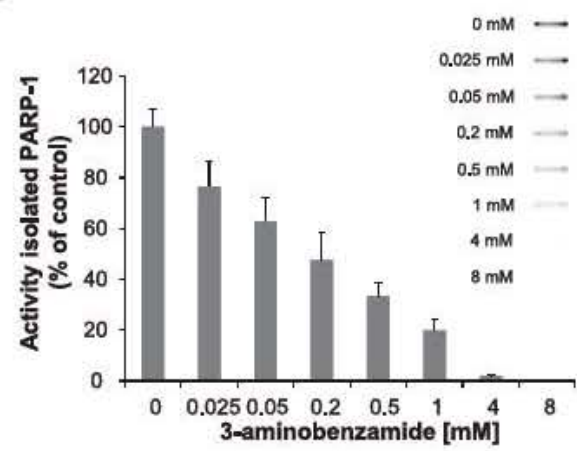

Figure 5. Effect of $\mathrm{Mn}$ on poly(ADP-ribose) polymerase-1 (PARP-1) protein level in CCFSTTG1 cells after 2-h $\mathrm{MnCl}_{2}$ incubation and a representative western blot (A). Impact of 3-aminobenzamide (B) or $\mathrm{MnCl}_{2}$ (C) on the activity of isolated PARP-1. After 2-min preincubation of PARP-1 with 3-aminobenzamide or $\mathrm{MnCl}_{2}$ at room temperature, PARP-1 reaction was carried out for $5 \mathrm{~min}$ and poly(ADP-ribose) was quantified by a immuno-slot-blot assay. Shown are mean values of at least four independent determinations + SD. 
A

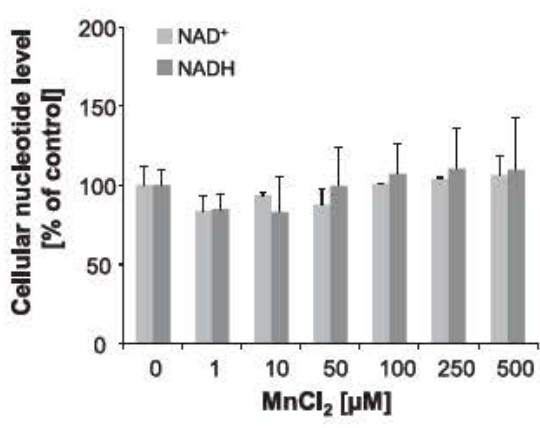

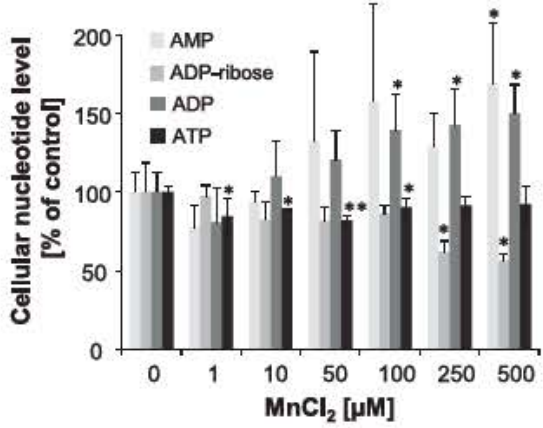

C

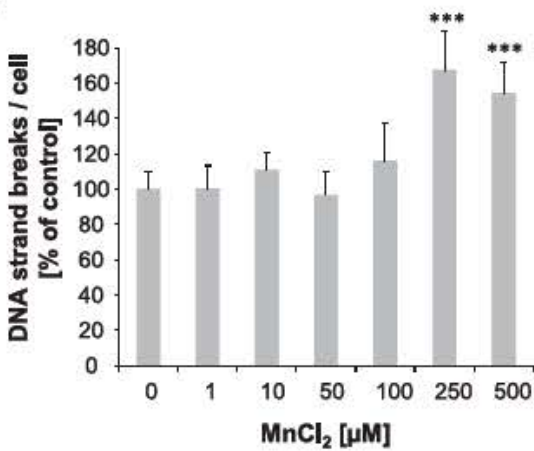

Figure 6. Impact of $\mathrm{MnCl}_{2}$ on the cellular levels of $\mathrm{NAD}^{+}$and $\mathrm{NADH}(\mathrm{A})$ as well as ATP, ADP, ADP-ribose, AMP (B) in CCFSTTG1 cells after 2-h $\mathrm{MnCl}_{2}$ incubation. Cells were treated with $\mathrm{MnCl}_{2}$ for $2 \mathrm{~h}$, extracts were prepared, and the nucleotides were measured with HPLC/DAD. Shown are mean values of at least three independent determinations + SD; $100 \%$ refer to the absolute levels of the respective nucleotides in control cells, respective means of controls are listed in [33]. (C) Effect of $\mathrm{MnCl}_{2}$ on DNA strand break induction by $\mathrm{H}_{2} \mathrm{O}_{2}$. CCF-STTG1 cells were preincubated with for $2 \mathrm{~h}$ and pretreated with $100 \mu \mathrm{M} \mathrm{H}_{2} \mathrm{O}_{2}$ for $5 \mathrm{~min}$ in the continued presence of $\mathrm{Mn}$. Shown are each mean values of at least three independent determinations with three measurements each + SD. decreased after 2-h $\mathrm{MnCl}_{2}$ incubation in CCF-STTG1 cells, while ADP $\left(\geq 100 \mu \mathrm{M} \mathrm{MnCl}_{2}\right)$ and AMP $\left(\geq 250 \mu \mathrm{M} \mathrm{MnCl}_{2}\right)$ levels were significantly increased (Fig. 6B).

\subsection{Effects on $\mathrm{H}_{2} \mathrm{O}_{2}$-induced DNA strand break formation}

After 2-h incubation a significant increase in DNA strand breaks after combined treatment of $250 \mu \mathrm{M} \mathrm{MnCl}_{2}$ or $500 \mu \mathrm{M} \mathrm{MnCl}_{2}$ with $100 \mu \mathrm{M} \mathrm{H}_{2} \mathrm{O}_{2}$ was observed when compared to $100 \mu \mathrm{M} \mathrm{H}_{2} \mathrm{O}_{2}$ alone (Fig. $6 \mathrm{C}$ ). This rules out that the observed inhibition of cellular $\mathrm{H}_{2} \mathrm{O}_{2}$-stimulated poly(ADP. ribosyl)ation is due to a lower number of DNA strand breaks induced after combined treatment of $\mathrm{MnCl}_{2}$ and $\mathrm{H}_{2} \mathrm{O}_{2}$ as compared to $\mathrm{H}_{2} \mathrm{O}_{2}$ alone. 24- or 48-h preincubation with $\mathrm{MnCl}_{2}$ did not significantly affect the number of strand breaks induced by $\mathrm{H}_{2} \mathrm{O}_{2}$ (data not shown).

\subsection{Mn content in infant formula}

Mn content in breast milk is generally quite low $(3-10 \mu \mathrm{g} / \mathrm{L})$ $[45,46]$. In contrast, Mn concentrations in infant formulas can vary dramatically, depending on the protein source and fortification in the manufacturing process. Here we determined total Mn levels in three cow milk-based infant formula as well as one goat milk and one soy milk-based infant formula. All three cow-based formula contained about 20 -fold more Mn than breast milk. In goat milk based infant formula

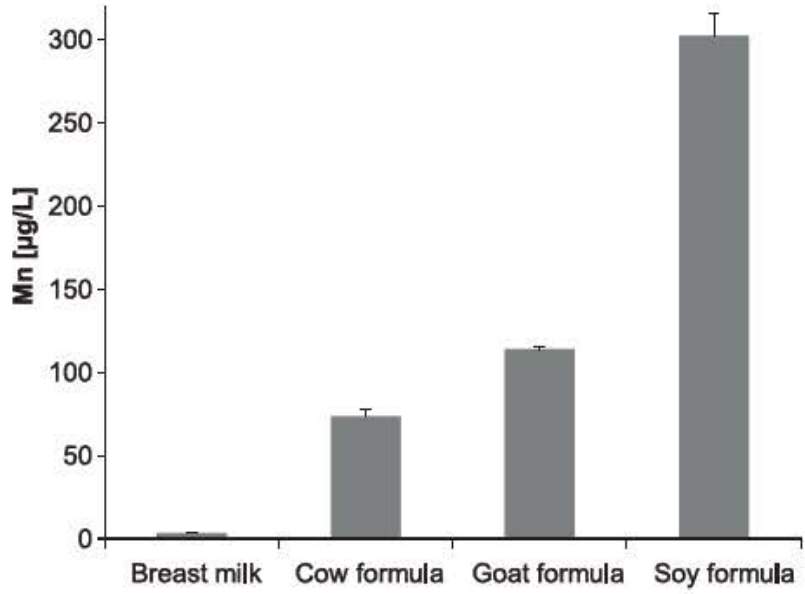

Figure 7. Manganese content in breast milk [46] and infant formula as determined by inductively coupled plasma emission spectrometry. The data represent mean values of at least four independent determinations $+\mathrm{SD}$.

$113.8 \pm 0.5 \mu \mathrm{g} / \mathrm{L}$ Mn were determined. Highest levels were examined in a soy formula, which contained a 100 -fold higher Mn content than breast milk (Fig. 7).

\section{Discussion}

The aim of this study was to study the impact of Mn treatment on human astrocytes by analyzing several critical biological 
endpoints, which are potentially related to Mn-induced toxicity, such as RONS generation, DNA damage, and poly(ADPribosyl)ation. Astrocytes, represent $\sim 50 \%$ of the brain volume [47] and are known to protect neurons against oxidative stress as well as to support neurons by fostering their survival, proliferation, differentiation, neurite outgrowth, and synaptogenesis. Moreover, astrocytes are discussed to be the primary place for $\mathrm{Mn}$ storage in the brain. In literature this led to the assumption that astrocytes are the primary target cells in Mn-induced neurotoxicity $[48,49]$. To correlate Mninduced effects with effective cellular Mn concentrations after incubation with $\mathrm{MnCl}_{2}$, Mn bioavailability as well as $\mathrm{Mn}$ release was investigated in cultured human astrocytes. These studies revealed a fast and efficient cellular Mn uptake. Thus cellular Mn concentrations reached a plateau after $0.5-1 \mathrm{~h}$ of $\mathrm{MnCl}_{2}$ incubation and remained at these subequimolar levels up to $48 \mathrm{~h}$ of incubation with $\mathrm{MnCl}_{2}$. In comparison to cultured rat astrocytes, which have been shown to accumulate $\mathrm{Mn}$ by a factor of 50 in relation to the surrounding culture media [50], uptake was much lower. Efflux of Mn from preloaded human astrocytes after replacement of the culture media by culture media not supplemented with $\mathrm{Mn}$ was nearly complete. This has been shown before in cultured rat astrocytes as well as in in vivo studies $[50,51]$. The release of $\mathrm{Mn}$ from astrocytes in response to a decrease of internal exposure levels might be a positive effect with the purpose to lower excessive Mn levels in the brain. However, it should be kept in mind that Mn efflux from the brain is believed to be rather small [41,52]. Furthermore, in case of Mn release from astrocytes, surrounding neurons are exposed to very high Mn levels, which might result in severe toxic effects in the respective neurons.

Generation of oxidative stress is often discussed as one possible mode of action of Mn-induced neurotoxicity. Various studies reported that Mn increases formation of RONS by inhibiting complex I-IV in brain mitochondria [53] as well as by disturbing the cellular oxidative defense systems [14,54-56]. In this context several authors observed RONS generation in brain associated cultured rat cells, including capillary endothelial cells, PC12 cells and astrocytes [14,57-60]. In human brain cells, RONS generation has not been observed so far. In contrast to the published massive time- and concentrationdependent increase of RONS in cultured rat astrocytes [49], in this study in cultured human astrocytes only a slight increase in the cellular RONS levels was observed after $\mathrm{MnCl}_{2}$ incubation. This might be partly due to the abovementioned differences in Mn bioavailability between rat and human astrocytes. In addition to the slight increase in RONS levels, at Mn concentrations of up to $100 \mu \mathrm{M}$ astrocytic ATP decreased slightly, followed by an increase in the ATP degradation products ADP and AMP. Mn accumulation in mitochondria has been reported to result in mitochondrial dysfunction, thereby impairing oxidative phosphorylation and ATP production $[59,61,62]$. As a consequence, ATP depletion might diminish ATP-dependent neuroprotective actions of astrocytes, including glutamate uptake capacity [63]. Additionally ATP depletion might disturb mitochondrial $\mathrm{Ca}^{2+}$ signaling in astrocytes [59].

The results of the fast and massive, up to $~ 200 \%$ increase in cellular RONS level in PBCECs are in line with previous findings in primary rat brain capillary endothelial cells [14] and provide further evidence that RONS formation in capillary endothelial cells is a key mediator of Mn-induced toxicity. In conclusion, the sensitivity of the Mn-induced RONS generation seems to depend on the brain cell type and the animal species tested.

Data from both cultured cells and laboratory animals regarding Mn-induced genotoxicity are inconsistent [6, 64-67]. In this study in cultured human astrocytes, Mn induced neither micronuclei nor DNA strand breaks, indicating that Mn is not directly genotoxic. However, Mn was able to disturb the cellular response following DNA strand break induction. In particular subcytotoxic Mn concentrations $\left(\geq 1 \mu \mathrm{M} \mathrm{MnCl}_{2}\right.$ ) efficiently decreased cellular DNA-damage-induced poly(ADPribosyl)ation. To our knowledge, this is the first study that provides a direct link between Mn and poly(ADP-ribosyl)ation in brain-associated cells. Poly(ADP-ribosyl)ation is rapidly activated in response to DNA strand breaks and is involved in many cellular processes including genomic stability, chromatin modulation, DNA repair, replication, telomere maintenance, and transcription [68]. Regarding the disturbance of this essential DNA damage signaling reaction, astrocytes are more sensitive than capillary endothelial cells, which is in contrast to the situation regarding induction of oxidative stress by Mn.

The observed decrease of cellular $\mathrm{H}_{2} \mathrm{O}_{2}$-induced poly(ADP-ribosyl)ation neither resulted from a delay of the signaling reaction nor from diminished formation of DNA strand breaks. Mn did not decrease PARP-1 gene expression or PARP-1 protein level after any time points investigated. After 2-h incubation PARP-1 gene expression was even increased, which suggests a counter-regulatory mechanism in order to maintain cellular poly(ADP-ribosyl)ation capacity. Likewise, after long-term incubation astrocytes seem to be able to adapt to $\mathrm{Mn}$ and to cope with $\mathrm{Mn}$-induced negative effects regarding damage-induced poly(ADP-ribosyl)ation. This might also explain the observed attenuation of the disturbance of the signaling reaction with an increase in $\mathrm{MnCl}_{2}$ incubation time. Likewise PARP-1, PARG gene expression was affected by $\mathrm{MnCl}_{2}$. Thus, it cannot be excluded that the observed inhibition of $\mathrm{H}_{2} \mathrm{O}_{2}$-induced poly(ADP-ribosyl)ation is partly due to an increase of PARG expression.

Both the determination of the cellular levels of $\mathrm{NAD}^{+} /$ $\mathrm{NADH}$ and the supplementation studies with the NAD ${ }^{+}$precursor NA $[69,70]$, clearly ruled out that the Mn-induced inhibition of $\mathrm{H}_{2} \mathrm{O}_{2}$-induced poly(ADP-ribosyl)ation is due to a limitation of the substrate $\mathrm{NAD}^{+}$. Although cellular NA supplementation resulted in a threefold increase of cellular $\mathrm{H}_{2} \mathrm{O}_{2}$-induced cellular poly(ADP-ribosyl)ation, Mn still exerted a similar disturbance of the signaling reaction. 
In this study neither $\mathrm{MnCl}_{2}$ nor any other Mn-species, formed in the culture media after incubation with $\mathrm{MnCl}_{2}$, diminished the activity of recombinant PARP-1. However, we cannot exclude that in living cells reduced damage-induced poly(ADP-ribosyl)ation might be due to an interaction of $\mathrm{Mn}$ with the cellular PARP-1 activity. Thus, inside the cell $\mathrm{Mn}^{2+}$ or $\mathrm{Mn}^{3+}$ species might be formed, e.g. Mn-citrate complexes, which could attack sensitive target sites of PARP-1, including its three zinc structures. The two N-terminal zinc fingers are the major contributors for DNA binding activity of PARP-1 to single and double strand breaks and in each zinc finger structure zinc is coordinated by three cysteine and one histidine residues $\left(\mathrm{Cys}_{2} \mathrm{His}_{1} \mathrm{Cys}_{1}\right)$. The third PARP-1 zinc binding structure (Cys4) is involved in protein-protein interactions that orchestrate PARP-1 activation [71]. Moreover, in the cellular system PARP-1 activity might also be disturbed by Mninduced RONS as well as a disturbance of the cellular redox state $[33,72]$.

A further putative scenario, involving the replacement of Zn-ions from easy accessible structural sites in enzymes by Mn $[73,74]$, could be that newly synthesized PARP-1 is incorporating $\mathrm{Mn}$ at one or more of the three zinc-binding motives. This would probably negatively impact on the enzymatic activity and could also lead to accelerated proteasomale degradation of PARP-1. To compensate, cells enhance transcription of PARP-1, resulting in normal steady-state levels of the protein. Of note, PARP-1 negatively autoregulates its own promoter by binding and stabilizing a weak stem-loop structure. This would explain the reduction in cellular PAR-synthesis upon stimulation with constant PARP-1 protein levels and despite enhanced transcription. Also, activity of recombinant PARP-1 in vitro would not be affected as this has already been properly folded, preventing fast replacement of $\mathrm{Zn}$ by Mn.

Dysregulation of PARP-activity is well known to cause severe cellular toxicity, both in case of overactivation and disturbance. In neurological disorders, such as stroke or neurotrauma, PARP inhibitors are discussed to hamper PARP overactivation, thereby protecting brain cells from energy depletion and consequently cell death $[20,75]$. On the other hand, quite recently Lee and colleagues reported that PARP-1 inhibition may cause disturbances in gene expression, which stimulates a genetic network that enhances oncogenic potential [76]. Moreover, PARP-1 inhibition is well known to result in diminished DNA repair, thereby causing genomic instability $[28,29]$. Numerous in vitro and in vivo studies reveal evidence that PARP-1 contribute to several DNA repair pathways including single strand break repair, base excision repair and double strand break repair [24, 26, 77-80]. As a consequence of PARP-1 inhibition, cells are hypersensitive to alkylating agents and ionizing radiation. Thus, an increase in DNA strand break formation or chromosomal aberrations was observed, resulting in sister chromatid exchanges or higher micronuclei frequency [81-84]. Consistent with diminished DNA strand break protection by PARP-1, in this study a 2-h incubation with $\mathrm{MnCl}_{2}(250-500 \mu \mathrm{M})$ resulted in a significantly increased amount of $\mathrm{H}_{2} \mathrm{O}_{2}$-induced strand breaks. Likewise a defective response towards DNA strand breaks has been shown in neurological disorders including Parkinson's disease, emphasizing the importance of DNA repair in neuronal homeostasis [16]. Whether the Mn-induced chromosomal aberrations and sister chromatid exchanges in vitro $[65,85]$ and in vivo [67] might be due to an inhibition of poly(ADP-ribosyl)ation is still unknown. PARP-1 is also a nuclear epigenetic regulator of mitochondrial DNA repair and transcription, and its inhibition results in an impairment of mitochondrial homeostasis and related bioenergetics [86]. Additionally inhibition of poly(ADP-ribosyl)ation might negatively affect other CNS proteins like alpha-synuclein and sirtuins [79, 87-89]. Alpha-synuclein accumulation and impairment of sirtuin function have been reported to be involved in neurodegenerative diseases $[90,91]$.

For an estimation of the exposure relevance of our findings, in literature there are only limited data available regarding $\mathrm{Mn}$ concentrations in mammalian brain tissues. To the best of our knowledge no data exist about Mn levels in astrocytes of humans. Physiological levels of $\mathrm{Mn}$ in brain tissues are thought to range from 2 to $8 \mu \mathrm{M}$ and to increase several fold upon overexposure in rodents and humans [12]. In this study damage-induced poly(ADP-ribosyl)ation was significantly inhibited already by $1 \mu \mathrm{M} \mathrm{MnCl}_{2}$. Taking into account the cellular bioavailability of $\mathrm{Mn}$ in the tested astrocytes, $1 \mu \mathrm{M} \mathrm{MnCl}_{2}$ refers to an effective cellular Mn level of $14 \mu \mathrm{M}$, which is in the range of brain levels upon overexposure.

Disturbance of DNA-damage-stimulated poly(ADPribosyl)ation is likely to result in increased numbers of DNA damage harboring, dysfunctional brain cells and might lead to neurological dysfunction. Since PARP-1 activation is also associated with neurite outgrowth and long-term memory, chronic PARP-1 inhibition might additionally compromise neurogenesis and learning abilities [92, 93]. In this context, recent epidemiological studies have reported associations between elevated dietary Mn exposure and neurobehavioral and neurocognitive deficits in children [94-97]. Infants, in particular neonates, are likely at greater risk for Mn neurotoxicity, which is partly due to their immature and therefore leaky blood brain barrier, but also results from their immature $\mathrm{Mn}$ excretion [98-100]. Important diet-related routes for Mn overexposure in neonates and infants include total parenteral nutrition [101] but also industrially manufactured baby formula $[46,102]$ and contaminated drinking water [94]. In this study we observed up to 100 -fold higher Mn levels in infant formula than in breast milk. These levels are in accordance with published data $[45,46,102,103]$, where Mn content in human breast milk ranged between 3 and $10 \mu \mathrm{g} / \mathrm{L}$, while that of soy- and cow-based formula was determined as 200 $300 \mu \mathrm{g} / \mathrm{l}$ and $30-75 \mu \mathrm{g} / \mathrm{L}$, respectively. However, the meaning of this massive Mn fortification of infant formula seems to be disputable. In the past high Mn fortification has been justified with strong differences in Mn bioavailability between breast milk and formula. Nevertheless, today it is known that in infants bioavailability of the naturally occurring Mn species in 
breast milk and the supplemented Mn species in formula is similar $[45,46]$.

Finally both the apparent Mn overexposure of formula consuming infants and the observed Mn-related disturbance of damage-induced poly(ADP-ribosyl)ation in human astrocytes at exposure-relevant concentrations indicate that in terms of Mn the existing guidelines for infant formula but also drinking water [10] should be critically reconsidered.

The authors would like to thank Prof. Dr. Hans-Joachim Galla (WWU Münster, Germany) for PBCEC and CCF-STTG1 cells and Prof. Dr. Uwe Karst (WWU Münster, Germany) for providing the ICP-OES (iCAP 6300, Thermo Fisher Scientific). This work was supported by the Graduate School of Chemistry (WWU Münster, Germany).

The authors have declared no conflict of interest.

\section{References}

[1] Christianson, D. W., Structural chemistry and biology of manganese metalloenzymes. Prog. Biophys. Mol. Biol. 1997, 67, 217-252.

[2] Takeda, A., Manganese action in brain function. Brain Res. Brain Res. Rev. 2003, 41, 79-87.

[3] Dobson, A. W., Erikson, K. M., Aschner, M., Manganese neurotoxicity. Ann. N. Y. Acad. Sci. 2004, 1012, 115-128.

[4] Roth, J. A., Homeostatic and toxic mechanisms regulating manganese uptake, retention, and elimination. Biol. Res. 2006, 39, 45-57.

[5] Flynn, M. R., Susi, P., Neurological risks associated with manganese exposure from welding operations-a literature review. Int. J. Hyg. Environ. Health 2009, 212, 459-469.

[6] Gerber, G. B., Leonard, A., Hantson, P., Carcinogenicity, mutagenicity and teratogenicity of manganese compounds. Crit. Rev. Oncol. Hematol. 2002, 42, 25-34.

[7] Ellingsen, D. G., Hetland, S. M., Thomassen, Y., Manganese air exposure assessment and biological monitoring in the manganese alloy production industry. J. Environ. Monit. 2003, 5, 84-90.

[8] Pan, D., Caruthers, S. D., Senpan, A., Schmieder, A. H. et al., Revisiting an old friend: manganese-based MRI contrast agents. Wiley Interdiscip. Rev. Nanomed. Nanobiotechnol. 2010, doi: 10.1002/wnan.116.

[9] Fitzgerald, K., Mikalunas, V., Rubin, H., McCarthey, R. et al., Hypermanganesemia in patients receiving total parenteral nutrition. JPEN J. Parenter Enteral. Nutr. 1999, 23, 333-336.

[10] Frisbie, S. H., Mitchell, E. J., Dustin, H., Maynard, D. M. et al., World Health Organization discontinues drinking water guideline for manganese. Environ. Health Perspect. 2012, 120, 775-778.

[11] Guilarte, T. R., Manganese and Parkinson's disease: a critical review and new findings. Environ. Health Perspect. 2010, $118,1071-1080$.
[12] Aschner, M., Erikson, K. M., Herrero Hernandez, E., Tjalkens, R., Manganese and its role in Parkinson's disease: from transport to neuropathology. Neuromolecular Med. 2009, 11, 252-266.

[13] Bowman, A. B., Kwakye, G. F., Hernandez, E. H., Aschner, M., Role of manganese in neurodegenerative diseases. J. Trace Elem. Med. Biol. 2011, 25, 191-203.

[14] dos Santos, A. P., Milatovic, D., Au, C., Yin, Z. et al., Rat brain endothelial cells are a target of manganese toxicity. Brain Res. 2010, 1326, 152-161.

[15] Alam, Z. I., Jenner, A., Daniel, S. E., Lees, A. J. et al., Oxidative DNA damage in the parkinsonian brain: an apparent selective increase in 8-hydroxyguanine levels in substantia nigra. J. Neurochem. 1997, 69, 1196-1203.

[16] Katyal, S., McKinnon, P. J., DNA strand breaks, neurodegeneration and aging in the brain. Mech. Ageing Dev. 2008, 129, 483-491.

[17] Bender, A., Krishnan, K. J., Morris, C. M., Taylor, G. A. et al., High levels of mitochondrial DNA deletions in substantia nigra neurons in aging and Parkinson disease. Nat. Genet. 2006, 38, 515-517.

[18] Kraytsberg, Y., Kudryavtseva, E., McKee, A. C., Geula, C. et al., Mitochondrial DNA deletions are abundant and cause functional impairment in aged human substantia nigra neurons. Nat. Genet. 2006, 38, 518-520.

[19] Weissman, L., Jo, D. G., Sorensen, M. M., de Souza-Pinto, N. C. et al., Defective DNA base excision repair in brain from individuals with Alzheimer's disease and amnestic mild cognitive impairment. Nucl. Acids Res. 2007, 35, 5545-5555.

[20] Strosznajder, R. P., Czubowicz, K., Jesko, H., Strosznajder, J. B., Poly(ADP-ribose) metabolism in brain and its role in ischemia pathology. Mol. Neurobiol. 2010, 41, 187-196.

[21] Woodhouse, B. C., Dianov, G. L., Poly ADP-ribose polymerase-1: an international molecule of mystery. DNA Repair (Amst.) 2008, 7, 1077-1086.

[22] Schreiber, V., Ame, J. C., Dolle, P., Schultz, I. et al., Poly(ADPribose) polymerase-2 (PARP-2) is required for efficient base excision DNA repair in association with PARP-1 and XRCC1. J. Biol. Chem. 2002, 277, 23028-23036.

[23] Gibson, B. A., Kraus, W. L., New insights into the molecular and cellular functions of poly(ADP-ribose) and PARPs. Nat. Rev. Mol. Cell Biol. 2012, 13, 411-424.

[24] Beneke, S., Buerkle, A., Poly(ADP-ribosyl)ation in mammalian ageing. Nucleic Acids Res. 2007, 35, 7456-7465.

[25] Meyer-Ficca, M. L., Meyer, R. G., Jacobson, E. L., Jacobson, M. K., Poly(ADP-ribose) polymerases: managing genome stability. Int. J. Biochem. Cell Biol. 2005, 37, 920-926.

[26] Yelamos, J., Farres, J., Llacuna, L., Ampurdanes, C. et al., PARP-1 and PARP-2: new players in tumour development. Am. J. Cancer Res. 2011, 1, 328-346.

[27] Alano, C. C., Garnier, P., Ying, W., Higashi, Y. et al., NAD+ depletion is necessary and sufficient for poly(ADP-ribose) polymerase-1-mediated neuronal death. J. Neurosci. 2010, 30, 2967-2978. 
[28] Yu, S. W., Wang, H., Dawson, T. M., Dawson, V. L., Poly(ADPribose) polymerase-1 and apoptosis inducing factor in neurotoxicity. Neurobiol. Dis. 2003, 14, 303-317.

[29] Kauppinen, T. M., Multiple roles for poly(ADPribose)polymerase-1 in neurological disease. Neurochem. Int. 2007, 50, 954-958.

[30] Javle, M., Curtin, N. J., The potential for poly (ADP-ribose) polymerase inhibitors in cancer therapy. Ther. Adv. Med. Oncol. 2011, 3, 257-267.

[31] Bornhorst, J., Ebert, F., Hartwig, A., Michalke, B. et al., Manganese inhibits poly(ADP-ribosyl)ation in human cells: a possible mechanism behind manganese-induced toxicity? J. Environ. Monit. 2010, 12, 2062-2069.

[32] von Wedel-Parlow, M., Woelte, P., Galla, H. J., Regulation of major efflux transporters under inflammatory conditions at the blood-brain barrier in vitro. J. Neurochem. 2009, 111, 111-118.

[33] Bornhorst, J., Ebert, F., Lohren, H., Humpf, H. U. et al., Effects of manganese and arsenic species on the level of energy related nucleotides in human cells. Metallomics 2012, 4, 297-306.

[34] Beneke, S., Meyer, K., Holtz, A., Huttner, K. et al., Chromatin composition is changed by poly(ADP-ribosyl)ation during chromatin immunoprecipitation. PLoS One 2012, 7, e32914.

[35] Kawamitsu, H., Hoshino, H., Okada, H., Miwa, M. et al., Monoclonal antibodies to poly(adenosine diphosphate ribose) recognize different structures. Biochemistry 1984, 23, 3771-3777.

[36] Ebert, F., Weiss, A., Bultemeyer, M., Hamann, I. et al., Arsenicals affect base excision repair by several mechanisms. Mutat. Res. 2011, 715, 32-41.

[37] Beneke, S., Alvarez-Gonzalez, R., Burkle, A., Comparative characterisation of poly(ADP-ribose) polymerase-1 from two mammalian species with different life span. Exp. Gerontol. 2000, 35, 989-1002.

[38] Beneke, S., Scherr, A. L., Ponath, V., Popp, O. et al., Enzyme characteristics of recombinant poly(ADP-ribose) polymerases-1 of rat and human origin mirror the correlation between cellular poly(ADP-ribosyl)ation capacity and species-specific life span. Mech. Ageing Dev. 2010, 131, 366-369.

[39] LFGB, LFGB § 64 L 00.00 19/1. Determination of trace elements in food. German Food and Feed Code 2003.

[40] Boumans, P. W. J. M., Inductively Coupled Plasma Emission Spectroscopy, Part 2: Applications and Fundamentals. John Wiley \& Sons, New York 1987.

[41] Bornhorst, J., Wehe, C. A., Huwel, S., Karst, U. et al., Impact of manganese on and transfer across blood-brain and blood-cerebrospinal fluid barrier in vitro. J. Biol. Chem. 2012, 287, 17140-17151.

[42] Kirsch-Volders, M., Plas, G., Elhajouji, A., Lukamowicz, M. et al., The in vitro MN assay in 2011: origin and fate, biological significance, protocols, high throughput methodologies and toxicological relevance. Arch. Toxicol. 2011, 85, 873-899.
[43] Rivera-Mancia, S., Rios, C., Montes, S., Manganese accumulation in the CNS and associated pathologies. Biometals 2011, 24, 811-825.

[44] Yokel, R. A., Manganese flux across the blood-brain barrier. Neuromolecular Med. 2009, 11, 297-310.

[45] Lonnerdal, B., Effects of milk and milk components on calcium, magnesium, and trace element absorption during infancy. Physiol. Rev. 1997, 77, 643-669.

[46] Ljung, K., Palm, B., Grandér, M., Vahter, M., High concentrations of essential and toxic elements in infant formula and infant foods-a matter of concern. Food Chem. 2011, 127, 943-951.

[47] Chen, Y., Swanson, R. A., The glutamate transporters EAAT2 and EAAT3 mediate cysteine uptake in cortical neuron cultures. J. Neurochem. 2003, 84, 1332-1339.

[48] Sengupta, A., Mense, S. M., Lan, C., Zhou, M. et al., Gene expression profiling of human primary astrocytes exposed to manganese chloride indicates selective effects on several functions of the cells. Neurotoxicology 2007, 28, 478-489.

[49] Giordano, G., Pizzurro, D., VanDeMark, K., Guizzetti, M. et al., Manganese inhibits the ability of astrocytes to promote neuronal differentiation. Toxicol. Appl. Pharmacol. 2009, 240, 226-235.

[50] Aschner, M., Gannon, M., Kimelberg, H. K., Manganese uptake and efflux in cultured rat astrocytes. J. Neurochem. $1992,58,730-735$.

[51] Aschner, M., Guilarte, T. R., Schneider, J. S., Zheng, W., Manganese: recent advances in understanding its transport and neurotoxicity. Toxicol. Appl. Pharmacol. 2007, 221, 131-147.

[52] Yokel, R. A., Crossgrove, J. S., Bukaveckas, B. L., Manganese distribution across the blood-brain barrier. II. Manganese efflux from the brain does not appear to be carrier mediated. Neurotoxicology 2003, 24, 15-22.

[53] Zhang, S., Zhou, Z., Fu, J., Effect of manganese chloride exposure on liver and brain mitochondria function in rats. Environ. Res. 2003, 93, 149-157.

[54] Huang, P., Li, G., Chen, C., Wang, H. et al., Differential toxicity of $\mathrm{Mn} 2+$ and $\mathrm{Mn} 3+$ to rat liver tissues: oxidative damage, membrane fluidity and histopathological changes. Exp. Toxicol. Pathol. 2012, 64, 197-203.

[55] Chtourou, Y., Trabelsi, K., Fetoui, H., Mkannez, G. et al., Manganese induces oxidative stress, redox state unbalance and disrupts membrane bound ATPases on murine neuroblastoma cells in vitro: protective role of silymarin. Neurochem. Res. 2011, 36, 1546-1557.

[56] Marreilha dos Santos, A. P., Lopes Santos, M., Batoreu, M. C., Aschner, M., Prolactin is a peripheral marker of manganese neurotoxicity. Brain Res. 2011, 1382, 282-290.

[57] Chen, C. J., Liao, S. L., Oxidative stress involves in astrocytic alterations induced by manganese. Exp. Neurol. 2002, 175, 216-225.

[58] Gunter, K. K., Aschner, M., Miller, L. M., Eliseev, R. et al., Determining the oxidation states of manganese in $\mathrm{PC} 12$ and nerve growth factor-induced PC12 cells. Free Radic Biol. Med. 2005, 39, 164-181. 
[59] Milatovic, D., Yin, Z., Gupta, R. C., Sidoryk, M. et al., Manganese induces oxidative impairment in cultured rat astrocytes. Toxicol. Sci. 2007, 98, 198-205.

[60] Zhang, F., Xu, Z., Gao, J., Xu, B. et al., In vitro effect of manganese chloride exposure on energy metabolism and oxidative damage of mitochondria isolated from rat brain. Environ. Toxicol. Pharmacol. 2008, 26, 232-236.

[61] Brouillet, E. P., Shinobu, L., McGarvey, U., Hochberg, F. et al., Manganese injection into the rat striatum produces excitotoxic lesions by impairing energy metabolism. Exp. Neurol. 1993, 120, 89-94.

[62] Gavin, C. E., Gunter, K. K., Gunter, T. E., Manganese and calcium efflux kinetics in brain mitochondria. Relevance to manganese toxicity. Biochem. J. 1990, 266, 329-334.

[63] Tang, K. S., Suh, S. W., Alano, C. C., Shao, Z. et al., Astrocytic poly(ADP-ribose) polymerase-1 activation leads to bioenergetic depletion and inhibition of glutamate uptake capacity. Glia 2010, 58, 446-457.

[64] Jiao, J., Qi, Y., Fu, J., Zhou, Z., Manganese-induced single strand breaks of mitochondrial DNA in vitro and in vivo. Environ. Toxicol. Pharmacol. 2008, 26, 123-127.

[65] Lima, P. D., Vasconcellos, M. C., Bahia, M. O., Montenegro, R. C. et al., Genotoxic and cytotoxic effects of manganese chloride in cultured human lymphocytes treated in different phases of cell cycle. Toxicol. In Vitro 2008, 22, 1032-1037.

[66] Sava, V., Mosquera, D., Song, S., Cardozo-Pelaez, F. et al., Effects of melanin and manganese on DNA damage and repair in PC12-derived neurons. Free Radic. Biol. Med. 2004, 36, 1144-1154.

[67] Joardar, M., Sharma, A., Comparison of clastogenicity of inorganic $\mathrm{Mn}$ administered in cationic and anionic forms in vivo. Mutat. Res. 1990, 240, 159-163.

[68] Hassa, P. O., Hottiger, M. O., The diverse biological roles of mammalian PARPS, a small but powerful family of polyADP-ribose polymerases. Front Biosci. 2008, 13, 3046-3082.

[69] Weidele, K., Kunzmann, A., Schmitz, M., Beneke, S. et al., Ex vivo supplementation with nicotinic acid enhances cellular poly(ADP-ribosyl)ation and improves cell viability in human peripheral blood mononuclear cells. Biochem. Pharmacol. 2010, 80, 1103-1112.

[70] Jackson, T. M., Rawling, J. M., Roebuck, B. D., Kirkland J. B., Large supplements of nicotinic acid and nicotinamide increase tissue NAD+ and poly(ADP-ribose) levels but do not affect diethylnitrosamine-induced altered hepatic foci in Fischer-344 rats. J. Nutr. 1995, 125, 1455-1461.

[71] Langelier, M. F., Ruhl, D. D., Planck, J. L., Kraus, W. L. et al., The $\mathrm{Zn} 3$ domain of human poly(ADP-ribose) polymerase1 (PARP-1) functions in both DNA-dependent poly(ADPribose) synthesis activity and chromatin compaction. $J$. Biol. Chem. 2010, 285, 18877-18887.

[72] Milatovic, D., Zaja-Milatovic, S., Gupta, R. C., Yu, Y. et al., Oxidative damage and neurodegeneration in manganeseinduced neurotoxicity. Toxicol. Appl. Pharmacol. 2009, 240 219-225.

[73] Lee, M. H., Pettigrew, D. W., Sander, E. G., Nowak, T., Bovine liver dihydropyrimidine amidohydrolase: $\mathrm{pH}$ dependencies of the steady-state kinetic and proton relaxation rate properties of the Mn(II)-containing enzyme. Arch. Biochem. Biophys. 1987, 259, 597-604.

[74] Haffner, P. H., Goodsaid-Zalduondo, F., Coleman, J. E., Electron spin resonance of manganese(II)-substituted zinc(II) metalloenzymes. J. Biol. Chem. 1974, 249, 6693-6695.

[75] Graziani, G., Szabo, C., Clinical perspectives of PARP inhibitors. Pharmacol. Res. 2005, 52, 109-118.

[76] Lee, M. H., Na, H., Kim, E. J., Lee, H. W. et al., Poly(ADPribosyl)ation of p53 induces gene-specific transcriptional repression of MTA1. Oncogene 2012, 31, 5099-5107.

[77] Caldecott, K. W., Single-strand break repair and genetic disease. Nat. Rev. Genet 2008, 9, 619-631.

[78] Hooten, N. N., Kompaniez, K., Barnes, J., Lohani, A. et al., Poly(ADP-ribose) polymerase 1 (PARP-1) binds to 8oxoguanine-DNA glycosylase (OGG1). J. Biol. Chem. 2011, 286, 44679-44690.

[79] Schreiber, V., Dantzer, F., Ame, J. C., de Murcia, G., Poly(ADP-ribose): novel functions for an old molecule. Nat. Rev. Mol. Cell Biol. 2006, 7, 517-528.

[80] Helleday, T., The underlying mechanism for the PARP and BRCA synthetic lethality: clearing up the misunderstandings. Mol. Oncol. 2011, 5, 387-393.

[81] Schwartz, J. L., Morgan, W. F., Weichselbaum, R. R., Different efficiencies of interaction between 3-aminobenzamide and various monofunctional alkylating agents in the induction of sister chromatid exchanges. Carcinogenesis 1985, 6, 699-704.

[82] de Murcia, J. M., Niedergang, C., Trucco, C., Ricoul, M. et al., Requirement of poly(ADP-ribose) polymerase in recovery from DNA damage in mice and in cells. Proc. Natl. Acad. Sci. U S A 1997, 94, 7303-7307.

[83] Wang, Z. Q., Stingl, L., Morrison, C., Jantsch, M. et al., PARP is important for genomic stability but dispensable in apoptosis. Genes Dev. 1997, 11, 2347-2358.

[84] Pachkowski, B. F., Tano, K., Afonin, V., Elder, R. H. et al., Cells deficient in PARP-1 show an accelerated accumulation of DNA single strand breaks, but not AP sites, over the PARP1-proficient cells exposed to MMS. Mutat. Res. 2009, 671, 93-99.

[85] Galloway, S. M., Armstrong, M. J., Reuben, C., Colman, S et al., Chromosome aberrations and sister chromatid exchanges in Chinese hamster ovary cells: evaluations of 108 chemicals. Environ. Mol. Mutagen. 1987, 10, 1-175.

[86] Lapucci, A., Pittelli, M., Rapizzi, E., Felici, R. et al., Poly(ADPribose) polymerase- 1 is a nuclear epigenetic regulator of mitochondrial DNA repair and transcription. Mol. Pharmacol. 2011, 79, 932-940.

[87] Adamczyk, A., Kazmierczak, A., Alpha-synuclein inhibits poly (ADP-ribose) polymerase-1 (PARP-1) activity via NOdependent pathway. Folia Neuropathol. 2009, 47, 247-251.

[88] Mao, Z., Hine, C., Tian, X., Van Meter, M. et al., SIRT6 promotes DNA repair under stress by activating PARP1. Science 2011, 332, 1443-1446.

[89] Benavente, C. A., Schnell, S. A., Jacobson, E. L., Effects of niacin restriction on sirtuin and PARP responses to photodamage in human skin. PLoS One 2012, 7, e42276. 
[90] Pifl, C., Khorchide, M., Kattinger, A., Reither, H. et al., alphaSynuclein selectively increases manganese-induced viability loss in SK-N-MC neuroblastoma cells expressing the human dopamine transporter. Neurosci. Lett. 2004, 354, 34-37.

[91] Guarente, L., Franklin, H., Epstein Lecture: Sirtuins, aging, and medicine. N. Engl. J. Med. 2011, 364, 2235-2244.

[92] Cohen-Armon, M., Visochek, L., Katzoff, A., Levitan, D. et al., Long-term memory requires polyADP-ribosylation. Science 2004, 304, 1820-1822.

[93] Visochek, L., Steingart, R. A., Vulih-Shultzman, I., Klein, R. et al., PolyADP-ribosylation is involved in neurotrophic activity. J. Neurosci. 2005, 25, 7420-7428.

[94] Bouchard, M. F., Sauve, S., Barbeau, B., Legrand, M. et al., Intellectual impairment in school-age children exposed to manganese from drinking water. Environ. Health Perspect. 2011, 119, 138-143.

[95] Menezes-Filho, J. A., Novaes Cde, O., Moreira, J. C., Sarcinelli, P. N. et al., Elevated manganese and cognitive performance in school-aged children and their mothers. Environ. Res. 2011, 111, 156-163.

[96] Hernandez-Bonilla, D., Schilmann, A., Montes, S., Rodriguez-Agudelo, Y. et al., Environmental exposure to manganese and motor function of children in Mexico. Neurotoxicology 2011, 32, 615-621.

[97] Kim, Y., Kim, B. N., Hong, Y. C., Shin, M. S. et al., Coexposure to environmental lead and manganese affects the intelligence of school-aged children. Neurotoxicology 2009, 30, 564-571.

[98] Cotzias, G. C., Miller, S. T., Papavasiliou, P. S., Tang, L. C., Interactions between manganese and brain dopamine. Med. Clin. North Am. 1976, 60, 729-738.

[99] Winder, B. S., Manganese in the air: are children at greater risk than adults? J. Toxicol. Environ. Health A 2010, 73, 156-158.

[100] Rubin, L. L., Staddon, J. M., The cell biology of the bloodbrain barrier. Annu. Rev. Neurosci. 1999, 22, 11-28.

[101] Alves, G., Thiebot, J., Tracqui, A., Delangre, T. et al., Neurologic disorders due to brain manganese deposition in a jaundiced patient receiving long-term parenteral nutrition. JPEN J. Parenter Enteral. Nutr. 1997, 21, 41-45.

[102] Aschner, J. L., Aschner, M., Nutritional aspects of manganese homeostasis. Mol. Aspects Med. 2005, 26, 353-362.

[103] Erikson, K. M., Thompson, K., Aschner, J., Aschner, M., Manganese neurotoxicity: a focus on the neonate. Pharmacol. Ther. 2007, 113, 369-377. 